INTIQAD: JURNAL AGAMA DAN PENDIDIKAN ISLAM

ISSN 1979-9950 (print) || ISSN 2598-0033 (online), http://jurnal.umsu.ac.id/index.php/intiqad DOI: $10.30596 /$ intiqad.v\%vi\%i.3702

Vol. 11, No. 2 (Desember 2019)

\title{
Pembelajaran Tauhid Pada Anak Usia Dini (Studi Tentang Formulasi dan Strategi Pembelajaran)
}

\author{
Laila Wardati $^{1 *}$, OK. M. Daniel Syahindra ${ }^{2}$, Leni Masnidar Nasution ${ }^{3}$ \\ Sekolah Tinggi Agama Islam (STAI) Sumatera Medan*1, 2 \\ Sekolah Tinggi Agama Islam (STAI) Serdang Lubuk Pakam ${ }^{3}$ \\ *1email: laila92warda@gmail.com, \\ 2email: okmdanielsyahinra21@gmail.com \\ 3 email: lenimasnidarnasution@yahoo.co.id
}

\begin{abstract}
This study aims to (1) Determine the formulation of early childhood tauhid learning materials in TK Rusyda Medan, (2) To find out the strategies used in early childhood learning in TK Rusyda Medan. The method used in this study is a qualitative method with a descriptive analysis approach. The results showed that in TK Rusyda Tauhid learning was carried out with a number of material formulations namely about the introduction of Allah, about the introduction of the religion they professed, about the consequences of a Muslim who is associated with piety and good social behavior, around Islamic symbols either in the form of images or in the form of Islamic songs. The several methods used are exemplary methods, habituation methods, singing methods, story methods, stories, advice methods.
\end{abstract}

Artikel Info

\section{Keywords : Learning, Tauhid, Early Childhood.}

\section{Abstrak}

Penelitian ini bertujuan untuk (1) Mengetahui formulasi materi pembelajaran tauhid anak usia dini di TK Rusyda Medan, (2) Untuk mengetahui strategi yang digunakan dalam pembelajaran anak usia dini TK Rusyda Medan. Metode yang digunakan dalam penelitian ini ialah metode kualitatif dengan pendekatan analisis deskriptif. Hasil penelitian menunjukkan bahwa Di TK Rusyda pembelajaran tauhid dilakukan dengan beberapa formulasi materi yakni seputar pengenalan terhadap Allah Swt, seputar pengenalan terhadap agama yang dianutnya, seputar konsekuensi dari seseoang yang beragama Islam yang dihubungkan dengan keshalehahan dan perilaku sosial yang baik, seputar simbol-simbol keislaman baik dalam bentuk gambar atau dalam bentuk lagu-kagu Islami. 
Adapun beberapa metode yang digunakan ialah metode keteladanan, metode pembiasaan, metode bernyanyi, metode cerita, kisah, metode nasihat.

\section{Kata Kunci : Pembelajaran, Tauhid, Anak Usia dini}

\section{A. Pendahuluan}

Dalam agama Islam pembelajaran mengenai tauhid adalah yang pertama dan paling utama. Disebut pertama sebab ia menjadi permulaan dari segala pembelajaran yang kelak akan diterima oleh siswa. Disebut paling utama sebab pembelajaran tauhid mejadi pembelajaran yang harus dan mutlak dipelajari oleh setiap muslim. Jika tidak dipelajari tentu akan berdampak negatif terhadap keyakinan seseorang pada agama yang dianutnya, bahkan terkhusus lagi terhadap sang peciptanya. ${ }^{1}$

Pembelajaran tauhid itu sendiri bertujuan untuk memberikan pemahaman dan keyakinan kepada siswa tentang keesaan Allah Swt. Dengan harapan siswa mampu untuk mengenal pencipta dan segala ciptaanya. Muara dari pemahanan dan keyakinan tersebut tentu menjadi seorang muslim yang taat dan benar dalam pengamalan

1 Abdullah Nashih Ulwan, Pedoman Pendidikan Anak dalam Islam, terj. Saifullah Kamalie dan Hery Noer Ali, Jilid II, (Semarang: Asy-Syifa, 1981), h. 178-179. keberagamaanya. Mengingat begitu urgennya pelajaran ini, maka tak salah jika pembelajaran ini mulai diajarkan sejak dini pada diri setiap muslim. ${ }^{2}$

Perlu diketahui bahwa pembelajaran Tauhid memiliki keunikan dan kekhasan yang tak sama dengan pelajaran lain. Salah satu kekhasanya itu terletak pada karakteristik pembelajarannya yang mengajarkan sesuatu yang abstrak. Sesuatu yang abstrak itu maksudnya ialah ghaib atau tak berwujud, seperti Allah, Malaikat, jin, syaitan, surga, neraka, dan sebagainya. Karena tidak berwujud tentu membutuhkan pemikiran yang ekstra agar walaupun tak tampak oleh mata (ghaib) dapat ditangkap oleh pemikiran siswa, bahkan lebih jauh lagi diyakini.

Seperti yang telah disebutkan di atas bahwa pembelajaran yang seperti ini tentu menguras tenaga dan pikiran para guru khususnya pada tingkat anak usia

${ }^{2}$ M. Quraish Shihab, Wawasan Alquran; Tafsir Maudhu'i atas pelbagai persoalan umat, (Bandung: Mizan, 2007), h. 284 
Vol. 11, No. 2 (Desember 2019)

dini. Sebab pada masa ini anak-anak lebih banyak belajar dari sesuatu yang konkret, dari pada sesuatu yang abstrak. Anak usia dini cenderung untuk memahami sesuatu objek yang keberadaanya dekat dengan mereka, objek pembelajaran tauhid bukan hanya jauh keberadaanya, namun tidak terlihat sama sekali. Kondisi ini tentu membuat guru menjadi dilema, sebab di satu sisi ia harus mengatakan bahwa objek tersebut tak dapat di lihat, dan di satu sisi ia harus mengatakan bahwa objek itu harus diyakini keberadaanya, walaupun tak dapat dilihat oleh mata.

Berhasil atau tidaknya pembelajaran ini bukanlah di tentukan dari seberapa tinggi keberimanan anakanak usia dini tersebut, tetapi dilihat dari perilaku yang muncul sebagai respon tentang keyakinannya terhadap keberadaaan Allah Swt. Pembelajran yang berhasil tentu akan berdampak pada perilaku anak yang baik terhadap Tuhannya, seperti menganggap Tuhan sebagai sesuatu yang menyenangkan, sesuatu yang menjadikan hidupnya berhasil dan sebagainya. Sebaliknya pembelajaran yang kurang berhasil, akan berdampak pada perilaku anak yang menganggap bahwa Tuhan adalah sesuatu yang membingungkan, menakutkan, bahkan sesuatu yang menyakitkan.

Walaupun anak-anak usia dini secara kondisi akal belum sanggup untuk menerima yang abstrak. Tetapi bukan berarti dalam hal ini guru mengabaikan atau menunggunya sampai dewasa. Dalam hal ini lah para guru dituntut untuk mengerahkan daya pikir dan kreativitasnya untuk merancang formulasi materi pelajaran yang sesuai dengan tingkatan usia mereka, sehingga lebih mudah untuk dicerna. Selain itu juga perlu untuk merancang strategi pembelajaran yang sesuai dengan kemampuan dan kondisi mental anak.

Uraian masalah di atas sebenarnya hampir terjadi di seluruh lembaga pendidikan anak usia dini, termasuk di TK Rusyda Medan (yang akan menjadi lokasi dalam peneliitian ini). Tetapi tentu masing-masing lembaga PAUD memiliki jurus atau strategi tersendiri dalam mengatasi mengajarkan materi Tauhid tesebut. Selanjutnya pada tulisan ini akan fokus pada dua hal saja, yakni formulasi materi pembelajaran tauhid pada anak usia dini, dan strategi pembelajaran tauhid untuk anak usia dini. Kedua hal tersebut akan di teliti 
pada TK Rusyda Medan.

Hasil penelitian ini tentu diharapkan dapat menjadi bahan masukan bagi para guru-guru lain, atau pengelola lembaga, atau praktisi yang begerak dalam dunia pendidikan AUD untuk lebih peduli tentang merancang formulasi dan strategi pembelajaran tauhid. Sebab bagaimanapun semua hal tersebut bermula dari masa anak usia dini, dan harus tetap di jaga sampai dewasa.

\section{B. Tujuan Penelitian}

Secara umum tujuan penelitian ini untuk mengetahui praktik pembelajaran anak usia dini yang dilakukan di TK Rusyda Medan namun fokus pembelajarannya hanya pada tauhid saja. Tetapi secara Spesifik tujuan penelitian ini dirangkum menjadi beberapa tujuan yakni:

Untuk mengetahui fomulasi materi pembelajaran tauhid anak usia dini di TK Rusyda Medan

Untuk mengetahui strategi yang digunakan dalam pembelajaran anak usia dini TK Rusyda Medan.

\section{Pendekatan dan Metode penelitian}

Penelitian ini menggunakan metode kualitatif, yakni metode yang secara natural mencari, menggali, dan mengumpulkan temuan-temuan baru, baik yang berkaitan dengan konsep, teori atau interpetasi dari kejadian atau setting yang berkonteks khusus. Penelitian ini juga berupaya ntukk menggambarkan fenomena dan fakta yang terdapat dari suatu kasus atau kejadian atau objek dari penelitian itu sendiri. Aktivitas mendeskripsikan ini tentu akan lebih banyak mengutamakan uraian kalimat dari si peneliti itu sendiri, tetapi pendeksripsian itu tentunya akan lebih natural jika dibarengi dengan fakta yang ada di lapangan. ${ }^{3}$

Adapun pendekatan yang dipergunakan ialah analisis deskriptif yakni penelitian yang melukiskan dan menggambarkan kondisi objek penelitian pada kondisi sekarang sebagaimana adanya sesuai dengan data dan fakta yang ada. Penelitian ini termasuk upaya secara sistematis dalam menggambarkan seluruh hal yang berkaitan dengan objek yang sedang diteliti. ${ }^{4}$

Creswell dalam hal ini mendefisinikannya sebagai studi yang berfokus pada narasi, ceritaa atau

\footnotetext{
${ }^{3}$ Masganti Sitorus, Metodologi Penelitian Pendidikan Islam, (Medan: IAIN Press, 2011), h. 135-136

${ }^{4}$ Lexy J. Moleong, Metodologi Peneltian Kualitatif, (Bandung: Remaja Rosdakarya, 2008), h.6.
} 
ISSN 1979-9950 (print) || ISSN 2598-0033 (online), http://jurnal.umsu.ac.id/index.php/intiqad

DOI: $10.30596 /$ intiqad.v\%vi\%i.3702

Vol. 11, No. 2 (Desember 2019)

deskripsi tentang serangkaian kejadian yang terkait dengan pengalaman kehidupan manusia. Dengan dengan begitu dalam penelitian ini biasanya cenderung untuk menceritakan kembali tentang pengalaman-pengalaman seseorang atau sesuatu yang dilihat oleh si peneliti itu sendiri, dari semua pengalaman itu akan diangkat kesesuainnya dengan permasalahan yang dibahas. $^{5}$

Dalam penelitian ini yang akan digambarkan ialah praktik dari pembelajaran yang selama ini telah berlangsung atau sedang berlangsung terkhusus pada pembelajaran tauhidnya. Setelah mendapatkan gambaran tentang pelaksanaanya lalu kemudian dianalisis secara mendalam, kemudian memberikan intepretasi terhadap temuan lapangan tersebut. Pembelajaran tauhid dalam hal ini maksudnya ialah pembelajaran pada bidang agama yang penekananya khusus pada materi mengenal Allah dan ciptaanya.

2. Lokasi dan Informan Penelitian

Yang menjadi lokasi penelitian dalam hal ini ialah TK Rusyda Medan

${ }^{5}$ Jhon W. Cceswell, Penelitian Kualitatif dan Desain Riset; Memilih di Antara Lima Pendekatan, (Yogyakarta: Pustaka Pelajar, 2015), h. viii. yang beralamat di jalan Marelan (pasar III) Lingkungan 24 Kecamatan Medan Marelan, Kota Medan. TK ini dipilih menjadi lokasi penelitian sebab semua siswa pada lembaga ini beragama Islam sehingga lebih seragam dan mudah untuk mengeneralisasikan data yang dapat. Di Samping itu lokasi penelitian ini terbilang unik, sebab pada dasarnya TK ini tidaklah berciri khas keislaman, namun pada praktiknya sangat menunjukkan nuansa keislaman di TK tersebut. Dan tidak seorangpun dari siswanya yang beragama selain dari agama Islam.

Sedangkan yang menjadi objek penelitian ialah siswa-siswi di TK Rusyda Medan yang total jumlahnya 59 orang, yang terbagi kepada dua rombongan belajar. Dua rombongan belajar ini memiliki umur yang seragam yakni antara 5-6 tahun. Keseluruhan siswa tersebut akan menjadi sasaran pembelajaran yang dilakukan oleh gurugurunya. Selain siswa yang menjadi target observasi, penelitian ini juga akan mengamati para guru dalam memberikan pembelajaran pada anak-anak didiknya. Sebagai tambahan data bahwa jumlah guru untuk tiap kelas terdapat tiga orang, dengan rincian dua guru pelajaran, dan 
satu guru khusus untuk mempelajari Alquran (Iqra').

Kepala sekolah juga akan menjadi informan penelitian, sebab seluruh proses pelaksanaan pembelajaran di bawah kontrol kepala sekolah. Dengan demikian kepala sekolah tentu mengetahui dan menjadi orang yang mensetujui tentang terlaksananya formulasi dan strategi pembelajaran tauhid tersebut. Di samping kepala sekolah orang tua atau wali dari anakanak tersebut juga akan menjadi sumber informasi penelitian, darinya akan lahir data-data yang terkait dengan perilaku mereka saat di rumah yang mencerminkan keyakinannya kepada Allah Swt.

\section{Metoe Pengumpulan Data}

Terdapat beberapa metode yang dipergunakan dalam penelitian ini, di antaranya metode observasi, wawancara, dan studi dokumentasi.

a. Observasi merupakan metode dimana peneliti mengamati langsung objek penelitian, dan mencatat serta memahami situasi-situasi yang ada kaitannya dengan data penelitian. ${ }^{6}$

6 Sugiyono, Metode Penelitian Kuantitatif, Kualitatif dan $R \& D$, (Bandung: Alfabeta, 2008), h. 145
Dalam penelitian ini jenis observasi yang digunakan ialah non partisipan, maksudnya dalam hal ini peneliti menjadi pengamat independent, atau dengan kata lain tidaklah terlibat secara langsung sebagai pengajar dilembaga tersebut. Metode Observasi ini digunakan untuk mengamati secara langsung dan independen proses pembelajaran yang dilaksanakan, dan lebih terkhusus lagi fokus mengamati pada materi pelajaran agama dan moral anak. Observasi juga dilakukan pada saat anak-anak berinteraksi dengan temannya satu sama lain, atau ketika berinteraksi dengan sumber belajarnya, hal ini dilakukan untuk mendapatkan informasi tentang respon dan persepsi siswa tentang materi pelajaran tauhid tersebut.

b. Wawancara merupakan metode yang digunakan dengan pola tanya jawab terhadap objek penelitian. Dalam hal ini wawancara yang digunakan ialah jenis tidak testuktur, hal ini dipilih dengan alasan untuk menjaga kenaturalan aktivitas, yang tidak menyebabkan anak-anak terganngu atau teralih perhatiannya ketika sedang kedatangan peneliti. 


\section{INTIQAD: JURNAL AGAMA DAN PENDIDIKAN ISLAM}

ISSN 1979-9950 (print) || ISSN 2598-0033 (online), http://jurnal.umsu.ac.id/index.php/intiqad

DOI: $10.30596 /$ intiqad.v\%vi\%i.3702

Vol. 11, No. 2 (Desember 2019)

Walaupun pertanyaan tidak tertulis, namun semua pertanyaan diajukan sesuai dengan kebutuhan penelitian, dalam arti konsisten terhadap alur penelitian. Wawancara juga dilakukan pada orang tua atau wali dari para siswa. Tanya jawab berisi tentang strategi orang tua dalam memperkenalkan Tuhan kepada anakanaknya, dan juga respon para orang tua tentang pertanyaan-pertanyan anak seputar ketauhidan.

c. Studi dokumentasi merupakan langkah yag ditempuh dengan jalan memilahmilih informasi dari dokumen yang ada terkait dengan sumber data penelitian, dalam hal ini bisa saja berbentuk Rencana Pelaksanaan Pembelajaran Harian (RPPH), buku ajar, buku pendamping, dan juga hasil evaluasi pembelajaran peserta didik. Dokumen-dokumen tersebut berperan untuk mengungkap formulasi materi pembelajaran yang di sajikan oleh para guru, baik guru utama maupun guru pendamping.

4. Analisis Data

Analisis data dalam penelitian ini dilakukan dengan beberapa tahapan yakni reduksi data (data reduction), menyajikan data (data display), penyimpulan (conclusion). Reduksi data maksudnya dalam hal ini ialah memilih data yang penting, membuat pola dari data yang telah terkumpul, serta merumuskannya dalam susunan data sistematis. Penyajian data maksudnya ialah memberikan uraian tentang data yang telah direduksi tersebut. Sedangkan penyimpulan maksudnya menarik kesimpulan dari data yang telah di reduksi dan disajikan tersebut. Jika ditambilkan dalam bentuk alur, proses Analisa data yang dimaksud seperti gambar di bawah ini:

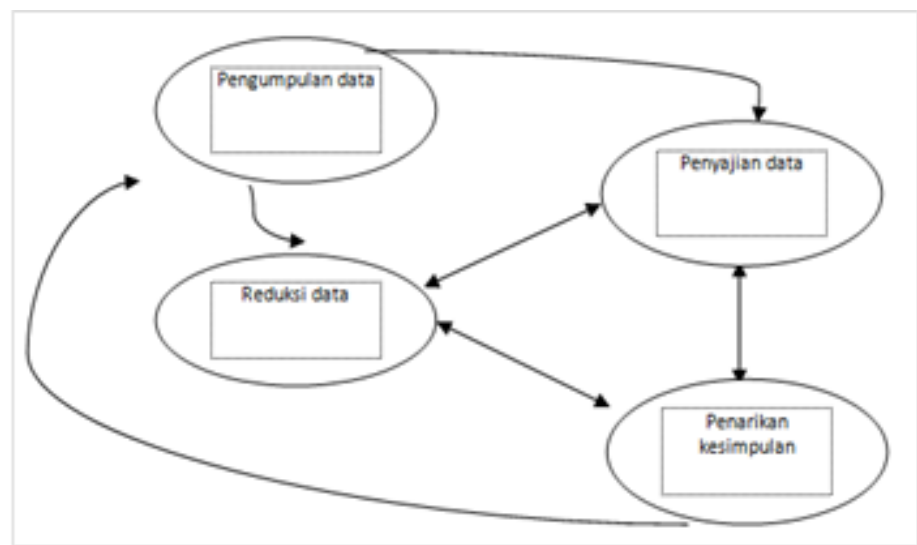

Gambar 1. Alur Analisa data kualitatif

\section{Pembahasan}

1. Formulasi Pembelajaran Tauhid

Dalam kebijakan pemerintah, seperti yang tertuang dalam Permendikbud RI Nomor 146 Tahun 2014 Tentang Kurikulum 2013 


\section{INTIQAD: JURNAL AGAMA DAN PENDIDIKAN ISLAM}

ISSN 1979-9950 (print) || ISSN 2598-0033 (online), http://jurnal.umsu.ac.id/index.php/intiqad

DOI: $10.30596 /$ intiqad.v\%vi\%i.3702

Vol. 11, No. 2 (Desember 2019)

Pendidikan Anak Usia Dini, tidak lah

ditemukan istilah pembelajaran tauhid.

Tetapi walaupun begitu bukan berarti di dalamnya tidak ada muatan pembelajaan bernuansa tauhid. Perlu dijelaskan dalam penelitian ini yang dimaksud dengan pembelajaran tauhid ialah pembelajaran yang fokus penekananya pada aspek akidah, dalam hal ini dapat berupa ketuhanan ataupun agama yang dianutnya. Tauhid yang dimaksud hanya sebatas pada aspek ketuhanan dalam perkembangan anak usia dini saja, bukan dalam artian tauhid dalam kajian sampai pada keyakinan yang hakiki sebagaimana layaknya yang selama ini dipelajari pada tingkatan usia dewasa. Apalagi sampai pada tataran ilmu kalam, atau pmbahasan sifat-sifat ketuhanan. Untuk selanjutnya Secara detail di bawah ini akan dipaparkan tentang kompetensi dasar yang berkaitan dengan spiritual siswa. Tujuan pemaparan ini tentu untuk menunjukkan tentang posisi pembelajaran tauhid:

Tabel 1 Kompetensi dasar dan indikator pencapaian aspek spiritual ${ }^{7}$

7 Uraian ini lihat lebih lanjut dalam peraturan Menteri Pendidikan dan Kebudayaan RI No Nomor 146 Tahun 2014 tentang Kurikulum k-13 Pendidikan Anak Usia Dini.

\begin{tabular}{|c|c|c|c|}
\hline No & Kompetensi Dasar & Umur & Indikator pencapaian \\
\hline 1 & $\begin{array}{l}\text { Mempercayai adanya } \\
\text { Tuhan melalui } \\
\text { Ciptaan-Nya }\end{array}$ & $5 \cdot 6$ & \multirow[b]{2}{*}{$\begin{array}{l}\text { Ndikator pencapaian perkembangan anak untuk } \\
\text { KD pada KI Sikap Spiritual dan KD pada KI } \\
\text { Sikap Sosial tidak dirumuskan secara } \\
\text { tersendiri. Pembelajaran untuk mencapai KD- } \\
\mathrm{KD} \text { ini dilakukan secara tidak langsung, tetapi } \\
\text { melalui pembelajaran untuk mencapai KD-KD } \\
\text { pada KI Pengetahuan dan KI Keterampilan, } \\
\text { serta melalui pembiasaan dan keteladanan. } \\
\text { Dengan kata lain, sikap positif anak akan } \\
\text { terbentuk ketika dia memiliki pengetahuan dan } \\
\text { mewujudkan pengetahuan itu dalam bentuk } \\
\text { hasil karya dan atau unjuk kerja Contoh sikap } \\
\text { positif itu adalah perilaku hidup sehat, jujur, } \\
\text { tanggung jawab, peduli, kreatif, kritis, percaya } \\
\text { diri, disiplin, mandiri, mampu bekerja sama, } \\
\text { mampu menyesuaikan diri, dan santun. }\end{array}$} \\
\hline 2 & $\begin{array}{l}\text { Menghargai diri } \\
\text { sendiri, orang lain, } \\
\text { dan lingkungan } \\
\text { sekitar sebaai rasa } \\
\text { syukur kepada } \\
\text { Tuhan }\end{array}$ & $5-6$ & \\
\hline \multirow[t]{5}{*}{3} & \multirow{5}{*}{$\begin{array}{l}\text { Mengenal kegiatan } \\
\text { beribadah sehari-hari } \\
\text { Melakukan kegiatan } \\
\text { beribadah sehari-hari } \\
\text { dengan tuntunan } \\
\text { orang dewasa }\end{array}$} & $5-6$ & $\begin{array}{l}\text { Mengucapkan doa-doa pendek, melakukan ibadah } \\
\text { sesuai dengan agama nya (misal: doa sebelum } \\
\text { memulai dan selesai kegiatan) }\end{array}$ \\
\hline & & $5-6$ & $\begin{array}{l}\text { Berperilaku sesuai dengan ajaran agama yang } \\
\text { dianutnva (misal: tidak bohong, tidak berkelahi) }\end{array}$ \\
\hline & & $5-6$ & Menyebutkan hari-hari besar agama \\
\hline & & 5.6 & Menyebutkan tempat ibadah agama lain \\
\hline & & $5 \cdot 6$ & $\begin{array}{l}\text { Menceritakan kembali tokoh-tokoh keagamaan } \\
\text { (misal: nabi-nabi) }\end{array}$ \\
\hline
\end{tabular}

Dari tabel yang dipaparkan di atas tampak bahwa tidaklah disebut istilah tauhid namun dari seluruh aspek spiritual yang ada, tampak bahwa kompetensi dasarnya dibedakan kepada dua hal saja yakni akidah dan ibadah. Akidah yakni kepercayaan terhadap Tuhan melalui Ciptaan-Nya, dan mensyukuri nikmat Allah Melalui menghargai diri sendiri, orang lain dan lingkungan. Sedangkan aspek ibadah yakni mengenal kegiatan ibadah agama yang dianutnya, dan melakukan kegiatan ibadah sehari-hari.

Jika dicermati tabel di atas dapatlah diambil kesimpulan bahwa untuk kompetensi dasar 'mempercayai 
ISSN 1979-9950 (print) || ISSN 2598-0033 (online), http://jurnal.umsu.ac.id/index.php/intiqad

DOI: 10.30596/intiqad.v\%vi\%i.3702

Vol. 11, No. 2 (Desember 2019)

Tuhan melalui Ciptaan-Nya' tidaklah dirumuskan secara baku indikatornya oleh pemerintah. Dengan begitu diserahkan sepenuhnya kpada lembaga pendidikan AUD masing-masing dalam merumuskannya, dan proses pencapaian rumusan tersebut dilakukan melalui pembelajaran spritual tak langsung, dalam arti para guru menargetkan untuk mencapai kompetensi dasar pada aspek kognitif dan psikomotorik, pencapaiannya itu akan membentuk sikap positif pada aspek spritualnya. Selain itu yang tepenting lagi melalui pembiasaan dan keteladanan. Dengan pembiasaan pada aspek spritualitas seperti mencontohkan rajin beribadah, rajin berdoa, mengenakan simbol-simbol sebagai seorang muslim, tentu akan menjadi sesuatu yang ditiru oleh anak.

Dalam mendeskripsikan

formulasi pembelajaran Tauhid di TK Rusyda, penulis menelusuri perangkat pembelajaran yang digunakan guru bersangkutan sebagai materi dan sumber belajar, di antaranya seperti buku ajar, buku majalah, dan Rencana Pembelajaran Harian (RPH). Dari beberapa sumber belajar tersebut dapatlah dijelaskan beberapa hal sebagai hasil penelitian yang telah diperoleh: a. Formulasi materi pelajaran tauhid di TK Rusyda berupa pengenalan terhadap Allah Swt dan agama yang dianutnya. Materi pengenalan terhadap Allah Swt berisi tentang uraian tentang status Allah sebagai pencipta manusia, alam semesta, dan Allah sebagai yang mengatur alam semesta, dan mengatur kehidupan manusia termasuk di dalamnya memberi makan, minum, menurunkan hujan dan mengatur siang dan malam.

b. Fomulasi materi pelajaran tauhid TK Rusyda berupa uraian tentang agama yang dianutnya, tetapi pada hal ini concernnya hanya sebatas pada penyebutan agama yang dianut oleh sang anak tersebut dan nama-anama agama lain. Dalam hal ini materi juga menguraikan tentang posisi agama Islam sebagai konskekuensi dari pengakuan tentang Allah sebagai pencipta alam semesta. Pada materi penghujung juga diuraikan sebagai materi tentang agama yang dianut oleh anak-anak tersebut bukanlah satu-satunya agama yang ada, melainkan ada agama lain.

Terkait dengan hal ini seperti yang dijelaskan oleh Sayyid Sabiq bahwa 


\section{INTIQAD: JURNAL AGAMA DAN PENDIDIKAN ISLAM}

ISSN 1979-9950 (print) || ISSN 2598-0033 (online), http://jurnal.umsu.ac.id/index.php/intiqad

DOI: $10.30596 /$ intiqad.v\%vi\%i.3702

Vol. 11, No. 2 (Desember 2019)
Semakin kurang tauhid seorang muslim, maka berefek terhadap penurunan kadar akhlak, watak, keperibadian, serta kemampuannya dalam menerima konsep Islam. Dengan kata lain ada hubungan antara kuatnya akidah seseoarang dengan baiknya etika dan moral seseorang. 8

c. Formulasi materi pelajaran tauhid di TK Rusyda juga berupa uraian tentang konsekuensi dari seseoang yang beragama Islam, yang dihubungkan dengan keshalehahan dan perilaku sosial yang baik. Seperti harus rajin mendirikan shalat, membaca Alquran, patuh dan taat kepada orang tua, sayang kepada adik dan kakak, dan cinta kebersihan. Dengan kata lain materi ini memberikan penekanan tentang ciri khas seoarang Muslim yang baik, dan memberikan kewaspadaan kepada peserta didik untuk tidak hanya sekedar beragama di lisan saja. Dalam hal ini perlu dijelaskan bahwa untuk formulasi materi pelajaran tauhid yang poin ke-3 ini

\footnotetext{
${ }^{8}$ Sayid Sabiq, Aqidah Islamiyah, (Jakarta: Robani Press, 2006), h. 8.
}

tidaklah di dapat melalui RPH atau buku ajar guru, melainkan dari penjelasan lisan sang guru ketika menjelaskan tentang materi pembelajaran tauhid.

Gambar 2. Formulasi materi pelajaran tauhid dengan paktik kebersihan

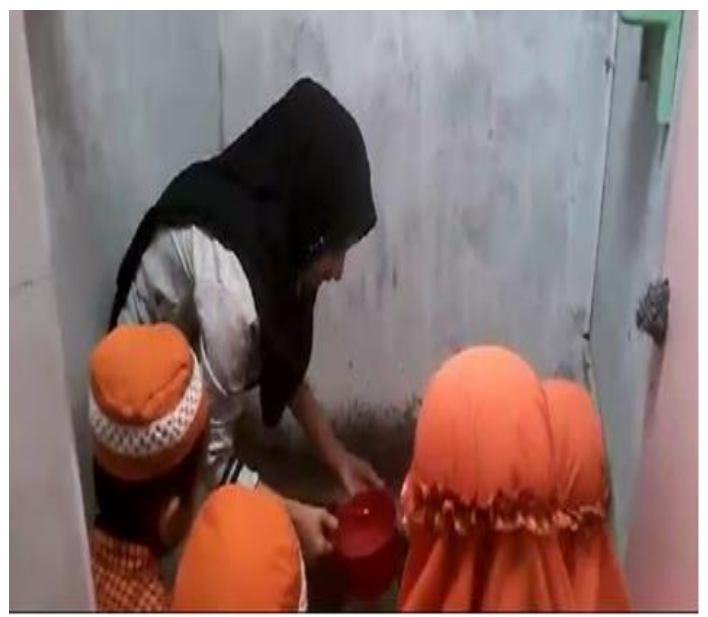

Materi pelajaran tauhid di TK Rusyda di sajikan dalam bentuk gambargambar, yang berkaitan dengan agama Islam. Gambar tesebut berupa simbolsimbol keagamaa Islam seperti masjid, gambar anak yang sedang mengenakan busana muslim, ka'bah dan sebagainya. Gambar-gambar tersebut seperti yang tertuang dalam buku majalah siswa (buku majalah ini pada dasarnya berfungsi sebagai pendamping). Sekilas memang gambar tersebut tidaklah berkaitan langsung dengan pembelajaran tauhid, namun hasil pengamatn 
INTIQAD: JURNAL AGAMA DAN PENDIDIKAN ISLAM

ISSN 1979-9950 (print) || ISSN 2598-0033 (online), http://jurnal.umsu.ac.id/index.php/intiqad

DOI: $10.30596 /$ intiqad.v\%vi\%i.3702

Vol. 11, No. 2 (Desember 2019) menunjukkan bahwa para guru di TK Rusyda menggunakannya sebagai cara untuk mengenalkan tentang Tuhan dan Islam sebagai agama yang dianutnya dan harus diyakninninya.

Gambar pada dasarnya disebut dengan media pembelajaran, namun dalam kasus ini tidaklah dapat sepenuhnya dikatakan demikian sebab, jika melihat buku pelajaran atau buku majalah (pendamping) anak Usia dini, sngat sedikit ditemukan tulisan dalam bentuk kata-kata, tetaapi lebih banyak ditemukan dalam bentuk gambar. Jika pun ada dalam bentuk kata-kata hanya ditujuakan sebagai panduan bagi guru nya saja. Itulah sebabnya dalam subab ini gambar masuk dalam kategori materi pelajaran.

Gambar 2. Materi pelajaran tauhid berbentuk gambar

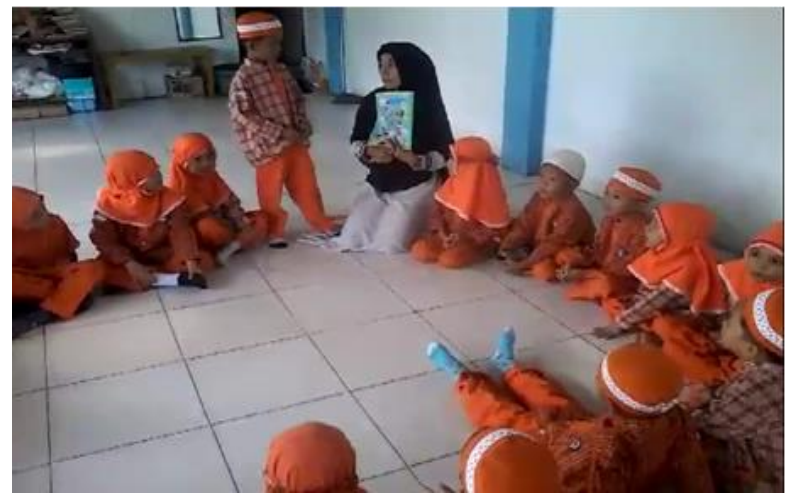

Formulasi materi pelajaran tauhid dalam hal pengenalan kepercayaan terhadap tuhan, dialakukan dengan tidak berpijak pada pemahaman dalil. Dalam hal ini guru lebih cenderung untuk berpijak dari sesuatu yang konkret, seperti menjelaskan bahwa adanya alam semesta sebagai kemahakuasaan Allah, adanya siang dan malam sebagai kuasanya Allah. Penjelasan juga dirahkan pada penjelasan mengenai sifat-sifat Allah yang mulia. Kekuasaan Allah tersebut lantas dijadikan guru sebagai landasan untuk membentuk persespsi siswa tentang sifat Allah terrsebut. Dijelaskan bahwa Allah besifat kasih sayang, Allah bersifat adil kepada seluruh makluknya, dan sebagainya. Dengan kata lain dalam penjelasan mengenai kepercayaan ataupun keimanan, para guru tidak mengajarkannya dalam formulasi yang konkret melainkan dalam formulasi yang abstrak.

Pada praktik pembelajaranya penulis juga mengamati bahwa formulasi materi pelajaran tentang kepercayaan terhadap tuhan dan agama yang dianutnya tampak dari lirik-lirik lagu yang sehari-hari dinyanyikan siswa. Liik-lirik lagu terrsebut berisi tentang kepercayaan terhadap Allah, dan keistimewaan agama Islam serta 
ISSN 1979-9950 (print) || ISSN 2598-0033 (online), http://jurnal.umsu.ac.id/index.php/intiqad

DOI: $10.30596 /$ intiqad.v\%vi\%i.3702

Vol. 11, No. 2 (Desember 2019)

konsekuensi agama yang dianutnya. Seperti contoh lirik lagu di bawah ini

'Allah Tuhan Kita satu, tanpa bapak ibu, Allah maha Esa, Allah maha Kuasa'. Tak lupa tugasku setiap hari, sembahyang wajibku yang lima kali subuh juhur ashar setiap hari, tak akan ku lupa selama-lamanya'.

\section{Strategi Pembelajaran Tauhid Pada}

\section{Anak Usia Dini}

Pada pembelajaran anak usia dini strategi pembelajaran disesuaikan dengan usia perkembangan anak. Pada Pembelajaran ini terdapat beberapa strategi yang digunakan, di antaranya sebagai berikut:

\section{Keteladanan}

Dengan strategi ini para guru dapat memberikan contoh tentang bagaimana seorang yang disebut beragama Islam itu. Di samping itu juga dapat mencontohkan bagaimana selayaknya seorang muslim itu berakhlakul karimah yang baik. Seperti yang teramati di TK Rusyda bahwa para guru memberikan ketaladanan dalam hal sebagai berikut:

Mengucapkan kalimat-kalimat yang baik (Thaiyibah), seperti memulai sesuatu dengan mengucapkan 'basmallah' dan mengakhiri sesuatu dengan mengucapkan 'alhamdulillah' hal ini dilakukan sebagai wujud perilaku sebagai seorang muslim yang senantiasa lisan dan hatinya ingat kepada Allah Swt.

Berbusana muslim dan muslimah, hal ini dilakukan sebagai wujud ilmplementasi dari keberagamaan Islam seseorang. Sekaligus memberikan keteladanan kepada siswa tentang perbedaan antara agama yang dianutnya dengan agama lain, bahwa agama Islam mengharuskan kita untuk berbusana yang menutup aurat.

Menunjukkan perilaku yang baik seperti saling tolong menolong, saling menghormati, saling sayang menyayangi, berkata yang lemah lembut. Perilaku itu ditunjukkan sebagai jati diri sebagai seorang muslim.

Menjaga lingkungan, dengan menyiram tanaman dan merawatnya. Hal ini dilakukan sebagai wujud keyakinan bahwa tumbuhan dan lingkungan merupakan ciptaan Allah Swt.

\section{Pembiasaan}

Strategi pembiasaan dilakukan untuk memberikan kebiasaan tentang perilakuperilaku yang menunjukkan sikap percaya kepada Allah Swt dan agama yang dianutnya. Hal ini tampak dari 
INTIQAD: JURNAL AGAMA DAN PENDIDIKAN ISLAM

ISSN 1979-9950 (print) || ISSN 2598-0033 (online), http://jurnal.umsu.ac.id/index.php/intiqad

DOI: $10.30596 /$ intiqad.v\%vi\%i.3702

Vol. 11, No. 2 (Desember 2019)

beberapa perilaku yang dirutinitaskan seperti di bawah ini:

Membiasakan siswa untuk selalu berdoa sebelum dan sesudah belajar, hal ini bertujuan untuk memberikan pemahaman kepada siswa bahwa harus senantiasa menghadirkan Allah dalam setiap aktivitas kehidupan. Dan dari penjelasan para guu juga tampak bahwa pembiasaan doa disampaikan oleh guru sebagai cara untuk mendapatkan kesuksesan dan keberhasilan dalam belajar.

Jika dianalisis tampak bahwa strategi yang dilakukan oleh guru bersifat simboisis, dalam arti terjadi efek timbal balik dari apa yang diusahak oleh siswa itu. Dalam hal para guru ingin memberikan kesan kepada siswa bahwa Allah lah yang maha kuasa dalam memberikan sesuatu keberhasilan kepada setiap orang yang dikehendakinya. Menurut wawancara penulis dengan salah satu guru pendamping tentang strategi pembiasaan ini, menurutnya dengan selalu membiasakan anak dekat dengan perilaku spritualitas, maka kelak perilaku tersebut akan permanen dan anak-anak tersebut akan selalu hidup dalam payung akidah yang islami.
Membiasakan siswa selalu berpakaian yang muslim dan muslimah. Hal ini bertujuan untuk menunjukkan identias sebagai seorang muslim yang menganut agama yang dianutnya. Para guru memberikan kebiasaan ini dimulai dari sejak dini, hal ini betujuan untuk menciptakan perilaku yang permanen kelak pada masa dewasa nanti. Menurut pengakuan para siswa ketika penulis wawancarai tentang busana yang dikenakannya, mereka menjawab bahwa pakaian yang mereka kenakan itu sebagai keharusan bagi seoarang muslim, dan sebagian lagi menjawab bahwa pakaian tersebut menunjukkan sebagai bentuk kerapian atau dalam artian pandangan estetikanya saja.

\section{Bernyanyi}

Metode ini dilakukan dengan nyanyiannyanyian yang benuansa ketauhidan, atau dalam artian yang mengandung nilai spritual yang penenkannanya tentang keimanan kepada Allah Swt. Nyanyian selalu dilakukan bersama-sama dalam aktivitas sebelum memasuki kelas dan sebelum meninggalkan kelas untuk pulang kerumah. Adapun nyanyian ini bahkan dalam keseharian dipandu oleh guru dengan bantuan alat musik sederhana seperti rebana, bahkan 
ISSN 1979-9950 (print) || ISSN 2598-0033 (online), http://jurnal.umsu.ac.id/index.php/intiqad

DOI: $10.30596 /$ intiqad.v\%vi\%i.3702

Vol. 11, No. 2 (Desember 2019)

terkdang juga menggunakan gitar.

Berdasarkan pengamatan penulis tentang lagu-lagu yang dinyanyikan, rata-rata lagu-lagu yang dimodifikasi oleh guru, dalam artian modifikasi pada lirik lagu yang sengaja digubah untuk sebagai strategi penyampaian materi pelajaran. Adapun contoh lirik lagunya dapat dilihat kembali pada sub bab pembahasan sebelumnya yakni pada huuf ' $\mathrm{f}$ ' subab formulasi materi pembelajaran tauhid. Selain itu ada juga modifikasi lagu 'balonku ada lima' dengan merubah liriknya menjadi 'rukun Islam dan rukun iman'.

Menurut pengakuan guru metode nyanyian ini dianggap sebagai metode yang paling efektif dalam memberikan pemahaman kepada siswa tentang ketauhidan, alasannya karena dengan stategi ini siswa tidak akan merasa terbebani dalam penyampaian pembelajaran. Ia kan dengan suka ria bernyanyi bersama dan dengan mudah untuk mengingatnya.

\section{Kisah/cerita}

Metode ini juga sering dilakukan guru, cerita dalam kaitannya dengan pembelajaran tauhid berupa cerita tetang alam semesta. Guru menceritakan bahwa alam semesta ini merupakan ciptaan
Allah Swt, sang guru membandingkan bahwa tidak ada satu orang pun yang mampu untuk menciptakan hal yang serupa dengan ciptaan Allah ini, oleh sebab itulah Allah disebut sebagai yang maha kuasa atas segala-galanya. Terjadinya siang dan malam juga menjadi cerita tambahan para guru, para guru di TK Rustda memberikan ilstrasi tentang bagaimana jika di malam hari yang membutuhkan lampu yang begitu banyak untuk dapat menerangi rumahrumah yang ada, tetapi disiang hari adakah orang yang mampu memberikan penerangan yang dapat menyinari seluruh pelosok alam semesta ini?.

Jika dianalisis apa yang dilakukan oleh guru ini sebenarnya ingin mengajarkan dengan pola comparative. Hal ini tampak dari pemberian contoh perbandingan antara kekuatan manusia dengan kekuatan Tuhan. Kekuatan Tuhan dalam hal ini terbatas, dan pada kondisi inilah guru memberikan pemahaman kepada siswa bahwa manusia yang lemah ini dikuasai oleh yang maha kuat, yakni Allah Swt.

\section{Nasihat}

Metode ini bersifat insidental, maksudnya tidak selau digunakan hanya digunakan pada awaktu tertentu saja, 
yakni pada saat terdapat siswa yang melakukan kesalahan, seperti perilaku yang tidak sopan, perkelahian antar siswa dan sebagainya. Metode ini digunakan untuk merubah perilaku buruk siswa tersebut dengan mengaitkannya dengan ketidaksukaan Allah terhadap perilakunya tersebut.

Pemberian metode nasihat ini bukanlah sebagai bentuk kemarahan atau punishment guru kepada peserta didiknya. Namun hanya sebatas untuk memberikan pemahaman kepada siswa tentan klasifikasi perbuatan manusia, bahwa terdapat perbuatan baik dan buruk. Dan sekaligus menunjukkan kepada siswa tersebut bahwa perbuatan yang dilakukannya salah dan memintanya untuk tidak mengulang perbuatan tersebut kembali.

Dari beberapa penjelasan di atas tetang bebeapa strategi yang digunakan dalam pembelajaran tauhid, tampak bahwa sebenarnya para guru tidaklah menggunakan stategi yang menghendaki para peserta didik untuk dapat meyakini Tuhan dalam artian keberimanan seperti layaknya orang dewasa. Strategi yang digunakan cenderung digunakan sesuai dengan tingkat usia anak usia dini. Sebagai tambahan pembahasan, William
Crain menyebutkan bahwa anak-anak belajar bukan dari sesuatu yang bersifat abstrak, akan tetapi belajar dari sesuatu yang bersifat konkret, Abstrak tidak dapat begitu saja dicerna oleh peserta didik sebab ia membutuhkan penalaran lebih, sedangkan yang konkret akan lebih mudah dipahami. ${ }^{9}$

Perlu juga ditambahkan bahwa sebenarnya proses pembelajaran tauhid pada anak usia dini ini tidak hanya menjadi tanggung jawab guru di sekolah, tetapi yang paling penting menjadi tanggung jawab orang tua. Sebab pendidikan awal itu bermula dari keluarga. ${ }^{10}$ Tanggung jawab orang tua dalam pendidikan tauhid pada dasarnya tugas untuk memelihara dan mengembangkan potensi fitrah yang ada pada setiap manusia. Mengenai fitrah Allah tegaskan pada Alquran yakni pada surah al-Rum [30]: 30:

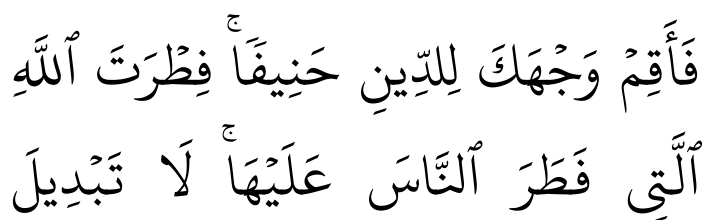

9 Wiiliam Crain, Teori Perkembangan, terj. Yudi Santoso, (Yogyakarta: Pustaka Pelajar, 2007), h. 2-3.

10 Jamal Abdurrahman, Parenting Rasulullah; Cara Nabi Mendidik Anak Muslim, terj. Ikhlas Syamsuir, (Yogyakarta: Pustaka Rama, 2008). 


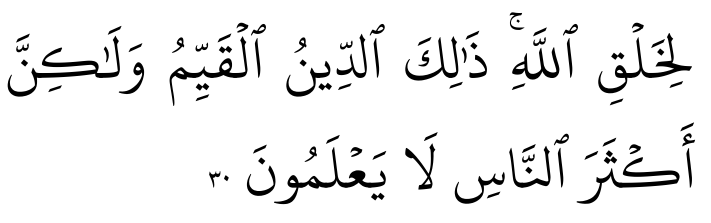

Artinya: Maka hadapkanlah wajahmu dengan lurus kepada agama Allah; (tetaplah atas) fitrah Allah yang telah menciptakan manusia menurut fitrah itu. Tidak ada perubahan pada fitrah Allah. (Itulah) agama yang lurus, tetapi kebanyakan manusia tidak mengetahui, Hamka Menjelaskan bahwa pemeliharaan dan pengembangan Fitrah merupakan tujuan utama dalam pendidikan Islam. Pengembangan fitrah ini menurutnya agar manusia dapat mengemban tugasnya sebagai seorang Khalifah di muka bumi ini. Dalam rangka mengamban tugasnya ini maka pendidikan Islam perlu untuk didesain kurikulum dan metodenya yang sesuai dengan kebutuhan fitrah manusia tersebut. Sebab jika tidak ia akan tumbuh tidak pada mestinya. Walaupun pada dasarnya fitrah tidak akan hilang sampai kapanpun, tetapi orang tersebutlah yang pada hakikatnya semakin jauh dari Fitrah tersebut. ${ }^{11}$

\footnotetext{
${ }^{11}$ Mohamad Salik, "Mengembangkan
} Fitrah anak Melalui pendidikan Islam (Studi Atas

\section{Simpulan}

Pendidikan tauhid merupakan sesuatu yang urgen pada setiap orang, dan pembelajaran ini sudah dimulai sejak manusia itu masih berusia belia, atau usia dini. Tentu beda usia beda pula formulasi dan strategi yang digunakan untuk memberikan pembelajaran tauhid ini. Di TK Rusyda pembelajaran tauhid dilakukan dengan beberapa formulasi materi yakni seputar pengenalan terhadap Allah Swt, seputar pengenalan terhadap agama yang dianutnya, seputar konsekuensi dari seseoang yang beragama Islam yang dihubungkan dengan keshalehahan dan perilaku sosial yang baik, seputar simbol-simbol keislaman baik dalam bentuk gambar atau dalam bentuk lagu-kagu Islami. Adapun beberapa metode yang digunakan ialah metode keteladanan, metode pembiasaan, metode bernyanyi, metode cerita.kisah, metode nasihat.

Pada prinsipnya seluruh pembelajaran tauhid untuk mengantarkan manusia kembali kepada fitrah penciptaanya, yakni potensi beragama atau mengenal sang

Pemikiran Hamka)", Jurnal el-Qudwah, Vol. 4 (2014). 
INTIQAD: JURNAL AGAMA DAN PENDIDIKAN ISLAM

ISSN 1979-9950 (print) || ISSN 2598-0033 (online), http://jurnal.umsu.ac.id/index.php/intiqad

DOI: $10.30596 /$ intiqad.v\%vi\%i.3702

Vol. 11, No. 2 (Desember 2019)

penciptanya. Potensi fitrah ini tidak menjadi tanggung jawab guru saja melainkan menjadi tanggug jawab orang tuanya.

\section{Daftar Pustaka}

Nashih Ulwan, Abdullah. (1981).

Pedoman Pendidikan Anak dalam Islam. terj. Saifullah Kamalie dan Hery Noer Ali, Jilid II. Semarang: Asy-Syifa

Jamal, Abdurrahman. (2008). Parenting Rasulullah; Cara Nabi Mendidik Anak Muslim, terj. Ikhlas Syamsuir. Yogyakarta: Pustaka Rama.

Jhon W, Cceswell. (2015). Penelitian Kualitatif dan Desain Riset; Memilih di Antara Lima Pendekatan. Yogyakarta: Pustaka Pelajar

Lexy J, Moleong, (2008). Metodologi Peneltian Kualitatif. Bandung: Remaja Rosdakarya

M. Quraish, Shihab. (2007). Wawasan Alquran; Tafsir Maudhu'i atas pelbagai persoalan umat. Bandung: Mizan
Sitorus, Masganti. (2011). Metodologi Penelitian Pendidikan Islam. Medan: IAIN Press

Salik, Mohamad. "Mengembangkan Fitrah anak Melalui pendidikan Islam (Studi Atas Pemikiran Hamka)". Jurnal el-Qudwah, Vol. 4 (2014).

Peraturan Menteri Pendidikan dan Kebudayaan RI No Nomor 146 Tahun 2014 tentang Kurikulum K13 Pendidikan Anak Usia Dini.

Sabiq, Sayid. (2008). Aqidah Islamiyah. Jakarta: Robani Press

Sugiyono. (2008). Metode Penelitian Kuantitatif, Kualitatif dan R \&D. Bandung: Alfabeta

Crain, Wiiliam. (2007). Teori Perkembangan, terj. Yudi Santoso. Yogyakarta: Pustaka Pelajar. 